\title{
The evaluation of the changes in enzymatic antioxidant reserves and lipid peroxidation in chosen parts of the brain in an animal model of Parkinson disease
}

\author{
Ewa B. Romuk ${ }^{1, A-D}$, Wioletta Szczurek ${ }^{1, B-D}$, Michał Oleś2, B, C, Artur Gabrysiak ${ }^{3, B, C}$, \\ Marta Skowron ${ }^{1, B, C}$, Przemysław Nowak ${ }^{2, A, E, F}$, Ewa Birkner, ${ }^{1, E, F}$ \\ ${ }^{1}$ Department of Biochemistry, Medical University of Silesia, School of Medicine with the Division of Dentistry, Zabrze, Poland \\ ${ }^{2}$ Department of Toxicology and Health Protection, Medical University of Silesia, School of Public Health, Katowice, Poland \\ ${ }^{3}$ FRYDA Medical Laboratory Ltd., Poland
}

\begin{abstract}
A - research concept and design; $B$ - collection and/or assembly of data; $C$ - data analysis and interpretation;
$\mathrm{D}$ - writing the article; $\mathrm{E}$ - critical revision of the article; $\mathrm{F}$ - final approval of article
\end{abstract}

Address for correspondence

Ewa Romuk

E-mail: eromuk@gmail.com

Funding sources

None declared

Conflict of interest

None declared

Received on November 16, 2015

Revised on February 14, 2016

Accepted on July 4, 2016

DOI

10.17219/acem/63999

Copyright

Copyright by Author(s)

This is an article distributed under the terms of the

Creative Commons Attribution Non-Commercial License

(http://creativecommons.org/licenses/by-nc-nd/4.0/)

\begin{abstract}
Background. Parkinson's disease is a progressive neurodegenerative disorder, characterized by the loss of dopaminergic neurons in the substantia nigra pars compacta. The causes of Parkinson's disease are not fully understood; however, increasing evidence implicates oxidative stress.
\end{abstract}

Objectives. The study was aimed at assessing the nature of the changes in the oxidation-antioxidant balance in the cerebral cortex, striatum, hippocampus, thalamus, and cerebellum in a rat model of Parkinson's disease (PD).

Material and methods. Sixteen male Wistar rats were divided into 2 groups: I- control, II- Parkinson's disease. The 8-weeks-old animals were decapitated, their brains removed and the following structures dissected and then frozen for further biochemical assays: cerebral cortex, striatum, hippocampus, thalamus and cerebellum. The activities of: the catalase (CAT), glutathione reductase (GR), glutathione peroxidase (GPX), glutathione S-transferase (GST), superoxide dismutase (SOD) and the isoenzymes: Cu/ZnSOD and MnSOD; together with the malondialdehyde (MDA) and the total oxidative status (TOS) concentrations were measured in each structure.

Results. A significantly increased activities of SOD, Cu/ZnSOD, GST and reduced GR activity and an increase of MDA concentration were observed in the striatum of $P D$ rats, comparing to the control group, combined with a significantly reduced activities of GR,SOD, Cu/ZnSOD and an increased GPX activity and MDA concentration in the hippocampus, a significantly lower GR, SOD, MnSOD, Cu/ZnSOD, and GST activities in the cerebral cortex. A significantly lower GR activity, higher CAT activity and MDA concentration in the thalamus and a significantly increased GR activity in the cerebellum were observed in PD rats compared to the corresponding control group.

Conclusions. Oxidative stress in PD involves many brain structures and various antioxidant enzymes and oxidative status parameters become dysfunctional, depending on the area of the brain, which might reflect the complexity of the clinical symptoms of PD.

Key words: oxidative stress, Parkinson disease, brain, antioxidant 
Parkinson's disease (PD) is a progressive neurodegenerative disorder, characterized by the loss of dopaminergic neurons in the substantia nigra of the midbrain, which results in a significant reduction in dopamine levels in the striatum. PD was the subject of many studies over the years; however, the factors causing selective neuronal cell death have not been clearly defined. Numerous studies suggest an increased exposure to free radicals, in combination with deficient antioxidant enzyme, might play an important role in neurodegeneration. ${ }^{1,2}$ PD is a multifactorial disease, and different mechanisms may be involved in the production of reactive oxygen species (ROS), and the interactions between them contribute to the severity of the degenerative processes of nerve cells. ${ }^{3}$ It is clear that the substantia nigra of the midbrain and the adjacent striatum are the most affected structures in the course of the analyzed disease. It should be noted, however, that the neurodegeneration in PD is not only limited to the dopaminergic pathways, but also include changes in other trails and structures of the brain, which can be damaged to varying degrees, reflecting the emergence of a variety of clinical symptoms. ${ }^{1,4}$

6-hydroxydopamine (6-OHDA) used in the experiment is a neurotoxin, which, applied to the lateral ventricles of the brain, causes a persistent, lifelong destruction of the dopaminergic nigrostriatal pathway and profound deficits of dopamine in the striatum. The resulting damage is proposed as a near-ideal model of advanced stage Parkinson's disease, which mimics human PD. ${ }^{5}$

The "free radical" hypothesis in PD has become the object of a number of experimental and clinical studies, but the role of oxidative stress and its devastating effects on different brain structures in PD have not been fully explained. Moreover, the results of studies on oxidative stress in PD are not homogeneous, and do not fully specify which antioxidant enzymes deplete and which indicators of oxidative stress are essential for the PD. ${ }^{2,4}$ In connection with data mentioned above, which is not fully precise in the available literature, this study was aimed to assess the role played by oxygen free radicals in the pathogenesis and course of $\mathrm{PD}$, and to thoroughly evaluate the oxidation-antioxidant balance in the different structures of the brain (in the striatum, frontal cortex, hippocampus, thalamus and cerebellum), in the experimental model of PD.

\section{Material and methods}

\section{Animals}

This experiment was performed on 16 male Wistar rats, weighing 180-200 g. The animals were housed under standard conditions of humidity (55-60\%), temperature $\left(21-22^{\circ} \mathrm{C}\right)$ and lighting (day-night: $12 / 12 \mathrm{~h}$ ) throughout the experimental period, with unlimited access to food and filtered water. Experimental procedures with the use of animals were conducted in accordance with recommendations in the Guide for the Care and Use of Laboratory Animals of the National Institutes of Health. The study protocol was approved by the Animal Experiments Local Ethics Committee of the Medical University of Silesia in Katowice (permit no. 33/2013). All efforts were made to minimize suffering.

\section{Research project}

Wistar newborns were divided into 2 groups and subjected to the following procedure:

- Group I: control rats: the 3-days-old neonatal rats were given desmethylimipramine in a dose of $20 \mathrm{mg}$ $/ \mathrm{kg}$, intraperitoneally (IP) in a volume of $1.0 \mathrm{~mL} / \mathrm{kg}$ and, after $60 \mathrm{~min}, 10 \mathrm{~mL}$ of $0.1 \%$ solution of ascorbic acid intraventriculary (ICV).

- Group II: rats with PD: the 3-days-old neonatal rats were given $20 \mathrm{mg} / \mathrm{kg}$ of desmethylimipramine IP in a volume of $1.0 \mathrm{~mL} / \mathrm{kg}$ and, after $60 \mathrm{~min}, 6$-hydroxydopamine in a dose of $15 \mathrm{mg} / 5 \mathrm{~mL}$ in $0.1 \%$ ascorbic acid solution into the right and left lateral ventricle of the brain.

The newborns were housed with their mothers until the age of 4 weeks, separated by gender and placed in separate cages for breeding thereon. After reaching the 8-week, the rats were decapitated. Then, after the opening the skull, brains were removed and the following structures of the brain were dissected: frontal cortex, striatum, hippocampus, thalamus, and cerebellum. The tissues were weighed and frozen on solidified $\mathrm{CO}_{2}$ (so-called "dry ice") and stored for further biochemical assays at $-80^{\circ} \mathrm{C}$.

\section{Tissues preparation}

Tissues were homogenized on ice, an UP50H ultrasonic processor (Hielscher) was used. The homogenates were centrifuged at $3000 \mathrm{rpm}$ for $10 \mathrm{~min}$, and supernatant was used for assay of the oxidant-antioxidant parameters.

\section{Biochemical analysis}

Glutathione reductase (GR) activity was measured by the modified method by Richterich. ${ }^{6}$ This method is based on a determination of changes in the concentration of reduced NADPH, which reacts with oxidized glutathione. The activity of GR was expressed as $\mu \mathrm{mol}$ of NADPH per minute per gram of protein (IU/g protein). The method is absolutely specific for glutathione reductase. Glutathione peroxidase (GPx) activity was measured by the kinetic method of Paglia and Valentine. ${ }^{7}$ In this method, GPx catalyzes the reaction between reduced glutathione (GSH) and t-butyl hyperoxide. The resulting oxidized glutathione (GSSG) is then converted back to the reduced form (GSH) by a NADPH-dependent glutathione reduc- 
tase (GR). The activity of GPx was expressed as micromoles of NADPH oxidized per minute normalized to gram of protein (IU/g Hb). Glutathione transferase (GST) activity was determined by kinetic method according to Habig. ${ }^{8}$ GST activity was expressed as $\mu \mathrm{mol}$ of thioether formed within 1 min per gram of protein (IU/g Hb). The method of Oyanagui was used to measure the activity of superoxide dismutase (SOD) and its izoenzymes: the cytoplasmic $\mathrm{Cu} / \mathrm{Zn}$-superoxide dismutase $(\mathrm{Cu} / \mathrm{Zn}$ SOD) and the mitochondrial Mn-superoxide dismutase (MnSOD) in brain's homogenates. ${ }^{9}$ In this method, xanthine oxidase produces superoxide anions which react with hydroxylamine forming nitric ions. These ions react with naphthalene diamine and sulfanilic acid generating a colored product. The concentration of this product is proportional to the amount of produced superoxide anions and negatively proportional to the activity of SOD. The enzymatic activity of SOD was expressed in nitric units. The activity of SOD is equal to 1 nitric unit (NU) when it inhibits nitric ion production by $50 \%$. Activities of SOD were normalized to milligram of protein in homogenates (NU/mg protein). Catalase (CAT) was measured by the Aebi kinetic method. ${ }^{10}$ The rate of decomposition of hydrogen peroxide was measured spectrophotometrically. The activity of catalase was expressed as units per milligram of protein (IU/mg protein). The malondialdehyde (MDA) level was determined by the Ohkawa method using a Perkin Elmer LS45 spectrofluorometer. ${ }^{11}$ The concentration of MDA was expressed as $\mathrm{mol} / \mathrm{g}$ of protein.

\section{Statistical analysis}

All statistical analyses were based on STATISTICA v. 10 program (StatSoft, Polska). The normality of the results distribution was verified using the Kolmogorov-Smirnov test, whereas Levene's test was used to verify homogeneity of variances. The data was analyzed using non-parametric Mann-Whitney U test and they were presented as median with the first and fourth quartiles. Value of $\mathrm{p}<0.05$ was considered to be statistically significant.

\section{Results}

In the cortex of the studied rats we have observed statistically significant decrease in GR (29\%), SOD (29\%), MnSOD (25\%) and CuZnSOD (31\%) activities in the 6 -OHDA group compared to that of the control rats (Table 1).

Results observed in the striatum showed us statistically significant increase in GST (25\%), SOD (25\%), CuZnSOD (15\%) activities and increase in MDA concentration (18\%) activity in the 6-OHDA group compared to that of the control rats. GR activity decreased in the 6-OHDA group (11\%) compared to that of the control rats (Table 2).
Table 1. Antioxidant enzymes activity and malondialdehyde concentration in cerebral cortex of studied groups of rats (U Mann-Whitney test)

\begin{tabular}{|c|c|c|c|}
\hline Cortex & Control & 6-OHDA & $p$-value \\
\hline $\begin{array}{l}\text { GR } \\
\text { [IU/g protein] }\end{array}$ & $\begin{array}{c}14.18 \\
{[12.63-15.08]}\end{array}$ & $\begin{array}{c}10.67 \\
{[8.83-12.46]}\end{array}$ & 0.009 \\
\hline $\begin{array}{l}\text { GPX } \\
\text { [IU/g protein] }\end{array}$ & $\begin{array}{c}7.02 \\
{[6.70-8.50]}\end{array}$ & $\begin{array}{c}7.14 \\
{[5.65-8.50]}\end{array}$ & ns \\
\hline $\begin{array}{l}\text { GST } \\
\text { [IU/g protein] }\end{array}$ & $\begin{array}{c}4.31 \\
{[4.21-4.78]}\end{array}$ & $\begin{array}{c}3.22 \\
{[3.12-4.01]}\end{array}$ & 0.001 \\
\hline $\begin{array}{l}\text { CAT } \\
\text { [kIU/g protein] }\end{array}$ & $\begin{array}{c}29.59 \\
{[28.30-34.00]}\end{array}$ & $\begin{array}{c}25.63 \\
{[22.43-35.60]}\end{array}$ & ns \\
\hline $\begin{array}{l}\text { SOD } \\
\text { [NU/mg protein] }\end{array}$ & $\begin{array}{c}31.76 \\
{[22.61-36.68]}\end{array}$ & $\begin{array}{c}18.33 \\
{[15.6-28.5]}\end{array}$ & 0.03 \\
\hline $\begin{array}{l}\text { MnSOD } \\
\text { [NU/mg protein] }\end{array}$ & $\begin{array}{c}12.65 \\
{[9.50-14.50]}\end{array}$ & $\begin{array}{c}7.99 \\
{[6.87-11.45]}\end{array}$ & 0.04 \\
\hline $\begin{array}{l}\text { CuZnSOD } \\
\text { [NU/mg protein] }\end{array}$ & $\begin{array}{c}19.11 \\
{[13.11-22.11]}\end{array}$ & $\begin{array}{c}10.34 \\
{[8.72-17.04}\end{array}$ & 0.03 \\
\hline $\begin{array}{l}\text { MDA } \\
\text { [umol/g protein] }\end{array}$ & $\begin{array}{c}1.22 \\
{[1.13-1.23]}\end{array}$ & $\begin{array}{c}1.06[ \\
0.93-1.34]\end{array}$ & ns \\
\hline
\end{tabular}

Table 2. Antioxidant enzymes activity and malondialdehyde concentration in striatum of studied groups of rats (U Mann-Whitney test)

\begin{tabular}{|c|c|c|c|}
\hline Striatum & Control & 6-OHDA & $p$-value \\
\hline $\begin{array}{l}\text { GR } \\
\text { [IU/g protein] }\end{array}$ & $\begin{array}{c}12.46 \\
{[10.94-12.99]}\end{array}$ & $\begin{array}{c}10.89 \\
{[10.54-11.59]}\end{array}$ & 0.03 \\
\hline $\begin{array}{l}\text { GPX } \\
\text { [IU/g protein] }\end{array}$ & $\begin{array}{c}11.59 \\
{[11.40-13.11]}\end{array}$ & $\begin{array}{c}12.48 \\
{[12.17-13.15]}\end{array}$ & ns \\
\hline $\begin{array}{l}\text { GST } \\
\text { [IU/g protein] }\end{array}$ & $\begin{array}{c}3.39 \\
{[3.03-3.49]}\end{array}$ & $\begin{array}{c}4.16 \\
{[3.72-4.49]}\end{array}$ & 0.0008 \\
\hline $\begin{array}{l}\text { CAT } \\
\text { [kIU/g protein] }\end{array}$ & $\begin{array}{c}45.92 \\
{[44.13-48.42]}\end{array}$ & $\begin{array}{c}46.25 \\
{[36.41-50.22]}\end{array}$ & ns \\
\hline $\begin{array}{l}\text { SOD } \\
\text { [NU/mg protein] }\end{array}$ & $\begin{array}{c}16.90 \\
{[15.96-18.33]}\end{array}$ & $\begin{array}{c}20.77 \\
{[18.63-23.40]}\end{array}$ & 0.009 \\
\hline $\begin{array}{l}\text { MnSOD } \\
\text { [NU/mg protein] }\end{array}$ & $\begin{array}{c}7.77 \\
{[7.08-8.28]}\end{array}$ & $\begin{array}{c}7.95 \\
{[7.39-9.59]}\end{array}$ & ns \\
\hline $\begin{array}{l}\text { CuZnSOD } \\
\text { [NU/mg protein] }\end{array}$ & $\begin{array}{c}9.96 \\
{[8.71-10.46]}\end{array}$ & $\begin{array}{c}11.45 \\
{[10.77-13.37]}\end{array}$ & 0.02 \\
\hline $\begin{array}{l}\text { MDA } \\
\text { [umol/g protein] }\end{array}$ & $\begin{array}{c}0.83 \\
{[0.8-0.87]}\end{array}$ & $\begin{array}{c}0.96 \\
{[0.88-1.09]}\end{array}$ & 0.03 \\
\hline
\end{tabular}

In the hippocampus we have observed increase in GPX activity (15\%) and MDA concentration (10\%) and decrease in GR (18\%), SOD (14\%), CuZnSOD (16\%) activity in the 6-OHDA group compared to that of the control rats (Table 3).

Results observed in the thalamus showed us statistically significant decrease in the GR activity (16\%) and increase in CAT activity (30\%) and MDA concentration (14\%) in the 6-OHDA group compared to that of the control rats (Table 4).

In the cerebellum we have observed statistically significant increase in GR activity (26\%) in the 6-OHDA group compared to that of the control rats (Table 5). 
Table 3. Antioxidant enzymes activity and malondialdehyde concentration in hipocampus of studied groups of rats (U Mann-Whitney test)

\begin{tabular}{|c|c|c|c|}
\hline Hipocampus & Control & 6-OHDA & $p$-value \\
\hline $\begin{array}{l}\text { GR } \\
\text { [IU/g protein] }\end{array}$ & $\begin{array}{c}11.45 \\
{[11.34-12.15]}\end{array}$ & $\begin{array}{c}10.20 \\
{[8.70-10.80]}\end{array}$ & 0.003 \\
\hline $\begin{array}{l}\text { GPX } \\
\text { [IU/g protein] }\end{array}$ & $\begin{array}{c}8.47 \\
{[8.02-9.06]}\end{array}$ & $\begin{array}{c}9.86 \\
{[9.18-10.83]}\end{array}$ & 0.02 \\
\hline $\begin{array}{l}\text { GST } \\
\text { [IU/g protein] }\end{array}$ & $\begin{array}{c}4.57 \\
{[4.41-4.96]}\end{array}$ & $\begin{array}{c}4.61 \\
{[4.24-5.04]}\end{array}$ & ns \\
\hline $\begin{array}{l}\text { CAT } \\
\text { [kIU/g protein] }\end{array}$ & $\begin{array}{c}42.36 \\
{[39.86-43.14]}\end{array}$ & $\begin{array}{c}41.73 \\
{[40.10-43.70]}\end{array}$ & ns \\
\hline $\begin{array}{l}\text { SOD } \\
\text { [NU/mg protein] }\end{array}$ & $\begin{array}{c}18.57 \\
{[17.56-18.86]}\end{array}$ & $\begin{array}{c}17.77 \\
{[16.51-18.50]}\end{array}$ & 0.05 \\
\hline $\begin{array}{l}\text { MnSOD } \\
\text { [NU/mg protein] }\end{array}$ & $\begin{array}{c}8.23 \\
{[7.78-8.89]}\end{array}$ & $\begin{array}{c}7.58 \\
{[5.87-8.18]}\end{array}$ & ns \\
\hline $\begin{array}{l}\text { CuZnSOD } \\
\text { [NU/mg protein] }\end{array}$ & $\begin{array}{c}10.36 \\
{[9.89-11.05]}\end{array}$ & $\begin{array}{c}9.44 \\
{[6.52-10.07]}\end{array}$ & 0.03 \\
\hline $\begin{array}{l}\text { MDA } \\
\text { [umol/g protein] }\end{array}$ & $\begin{array}{c}1.02 \\
{[0.96-1.05]}\end{array}$ & $\begin{array}{c}1.07 \\
{[0.90-1.20]}\end{array}$ & ns \\
\hline
\end{tabular}

Table 4. Antioxidant enzymes activity and malondialdehyde concentration in thalamus of studied groups of rats (U Mann-Whitney test)

\begin{tabular}{|c|c|c|c|}
\hline Thalamus & Control & 6-OHDA & $p$-value \\
\hline $\begin{array}{l}\text { GR } \\
\text { [IU/g protein] }\end{array}$ & $\begin{array}{c}7.43 \\
{[6.79-8.04]}\end{array}$ & $\begin{array}{c}6.58 \\
{[6.03-6.60]}\end{array}$ & 0.03 \\
\hline $\begin{array}{l}\text { GPX } \\
\text { [IU/g protein] }\end{array}$ & $\begin{array}{c}6.67 \\
{[5.93-7.31]}\end{array}$ & $\begin{array}{c}6.71 \\
{[6.46-6.82]}\end{array}$ & ns \\
\hline $\begin{array}{l}\text { GST } \\
\text { [IU/g protein] }\end{array}$ & $\begin{array}{c}2.56 \\
{[2.39-3.17]}\end{array}$ & $\begin{array}{c}1.73 \\
{[2.45-3.19]}\end{array}$ & ns \\
\hline $\begin{array}{l}\text { CAT } \\
\text { [kIU/g protein] }\end{array}$ & $\begin{array}{c}25.22 \\
{[22.96-35.01]}\end{array}$ & $\begin{array}{c}36.09 \\
{[30.60-41.10]}\end{array}$ & 0.04 \\
\hline $\begin{array}{l}\text { SOD } \\
\text { [NU/mg protein] }\end{array}$ & $\begin{array}{c}12.89 \\
{[11.02-14.05]}\end{array}$ & $\begin{array}{c}13.18 \\
{[10.95-14.30]}\end{array}$ & ns \\
\hline $\begin{array}{l}\text { MnSOD } \\
\text { [NU/mg protein] }\end{array}$ & $\begin{array}{c}5.95 \\
{[5.24-6.68]}\end{array}$ & $\begin{array}{c}5.90 \\
{[5.20-6.50]}\end{array}$ & ns \\
\hline $\begin{array}{l}\text { CuZnSOD } \\
\text { [NU/mg protein] }\end{array}$ & $\begin{array}{c}6.86 \\
{[5.78-7.48]}\end{array}$ & $\begin{array}{c}7.12 \\
{[5.78-7.90]}\end{array}$ & ns \\
\hline $\begin{array}{l}\text { MDA } \\
\text { [umol/g protein] }\end{array}$ & $\begin{array}{c}0.57 \\
{[0.51-0.67]}\end{array}$ & $\begin{array}{c}0.59 \\
{[0.54-0.68]}\end{array}$ & ns \\
\hline
\end{tabular}

\section{Discussion}

The balance of the oxidation-antioxidant system in neurodegenerative diseases has been the subject of intense experimental and clinical studies over the past few years. Plentiful evidence suggests that the cell aging processes and progressive neurodegeneration are closely associated with oxidative stress. Although the definitive cause of nigral dopamine neuron loss remains unknown, oxidative stress is the greatest risk factor for PD. Oxidative stress has been defined as a state of impaired oxidation-antioxidant balance, in the direction of oxidation, which is caused by excessive production of ROS and antioxidant mechanisms inability to detoxify them. ${ }^{12}$ Even
Table 5. Antioxidant enzymes activity and malondialdehyde concentration in thalamus of studied groups of rats (U Mann-Whitney test)

\begin{tabular}{|c|c|c|c|}
\hline Cerebellum & Control & 6-OHDA & $p$-value \\
\hline $\begin{array}{l}\text { GR } \\
\text { [IU/g protein] }\end{array}$ & $\begin{array}{c}7.74 \\
{[6.86-8.24]}\end{array}$ & $\begin{array}{c}10.23 \\
{[8.03-11.65]}\end{array}$ & 0.03 \\
\hline $\begin{array}{l}\text { GPX } \\
\text { [IU/g protein] }\end{array}$ & $\begin{array}{c}10.00 \\
{[9.23-10.52]}\end{array}$ & $\begin{array}{c}9.95 \\
{[7.90-11.30]}\end{array}$ & ns \\
\hline $\begin{array}{l}\text { GST } \\
\text { [IU/g protein] }\end{array}$ & $\begin{array}{c}2.22 \\
{[2.13-2.35]}\end{array}$ & $\begin{array}{c}2.09 \\
{[1.59-2.36]}\end{array}$ & ns \\
\hline $\begin{array}{l}\text { CAT } \\
\text { [kIU/g protein] }\end{array}$ & $\begin{array}{c}51.33 \\
{[48.65-61.50]}\end{array}$ & $\begin{array}{c}50.48 \\
{[47.81-65.45]}\end{array}$ & 0.04 \\
\hline $\begin{array}{l}\text { SOD } \\
\text { [NU/mg protein] }\end{array}$ & $\begin{array}{c}11.65 \\
{[10.72-14.08]}\end{array}$ & $\begin{array}{c}13.58 \\
{[9.84-14.79]}\end{array}$ & ns \\
\hline $\begin{array}{l}\text { MnSOD } \\
\text { [NU/mg protein] }\end{array}$ & $\begin{array}{c}5.51 \\
{[5.17-6.56]}\end{array}$ & $\begin{array}{c}6.04 \\
{[4.52-6.98]}\end{array}$ & ns \\
\hline $\begin{array}{l}\text { CuZnSOD } \\
\text { [NU/mg protein] }\end{array}$ & $\begin{array}{c}6.14 \\
{[5.66-7.51]}\end{array}$ & $\begin{array}{c}7.17 \\
{[5.32-7.75]}\end{array}$ & ns \\
\hline $\begin{array}{l}\text { MDA } \\
\text { [umol/g protein] }\end{array}$ & $\begin{array}{c}0.75 \\
{[0.69-0.86]}\end{array}$ & $\begin{array}{c}0.61 \\
{[0.46-0.76]}\end{array}$ & ns \\
\hline
\end{tabular}

though there are numerous defense mechanisms against free radicals in the body, it appears that the brain is exposed to an increasingly damaging effects of ROS compared to peripheral organs. ${ }^{1}$ Although the adult human brain represents only $2 \%$ of the body weight, it consumes almost $20 \%$ of the total amount of oxygen absorbed by the body. Such excessive oxidative metabolism favors the generation of oxygen free radicals. Excessive ROS generation is harmful to the cell membrane and may damage the nerve cells. Additionally, the high levels of polyunsaturated fatty acids in cell membranes of neurons and relatively low levels of antioxidants in brain tissues, as compared to other organs, make them more susceptible to the damage caused by ROS. ${ }^{3,12}$

Nerve cells are protected from the damaging effect of ROS under physiological conditions, but in the course of PD the depletion of the reserves of the antioxidant mechanisms is observed. Our results show that in the striatum of the rats with PD, the severity of oxidative stress is observed, as evidenced by the significantly higher level of MDA compared to healthy individuals. MDA is a marker of lipid peroxidation, which is significantly accumulated in striatum of the subjects with PD, as compared to the other areas of the brain and comparing to the control group. ${ }^{13}$ In addition, we observed a significant increase in the activity of SOD, $\mathrm{Cu} / \mathrm{ZnSOD}, \mathrm{GST}$, and a serious reduction in the activity of the GR in the striatum of the subjects with PD, compared to the control group. On the other hand, another study has shown that the antioxidant activity is reduced in the striatum of the rats with PD and it appears to be a key determinant of the susceptibility to damage of the dopaminergic neurons. ${ }^{14}$ These differences between the results can be explained on the basis of the duration of the test, because the longer the observation 
time, the greater is the extent of the marked symptoms of the increased oxidative stress. Our results indicate a stimulation of the antioxidant system in response to the increased lipid peroxidation and an increase in the free radicals levels, which is aimed to protect the nerve cells from oxidative damage. It is believed that this increase may be temporary. The defense mechanisms are depleted as a result of continuously sustained oxidative stress, which is observed in PD.

An important role for the protection of neurons against oxidative stress is played by SOD and its 2 fractions: $\mathrm{Cu}$ / $\mathrm{ZnSOD}$, and MnSOD. Those enzymes catalyze the removal of the toxic superoxide radical by converting it into hydrogen peroxide and molecular oxygen. ${ }^{15}$ Research indicates that overexpression of SOD and its isoenzymes may protect efficiently against neuronal loss. ${ }^{16}$ Our findings also support this hypothesis. Moreover, the study by Choi et al. has shown that oxidative modifications of $\mathrm{Cu}$ / ZnSOD might contribute to the pathogenesis of PD. ${ }^{17}$

In turn, glutathione reductase catalyzes the reduction of the oxidized form of glutathione (GSSG) in the presence of NADPH, the donor of electron necessary to restore the reduced form of glutathione (GSH). GSH depletion rate correlates positively with the severity of the disease and the ratio of GSH/GSSG is an important indirect indicator of the loss of dopaminergic neurons. The GSH deficiency causes an increase of the $\mathrm{H}_{2} \mathrm{O}_{2}$ concentration, which is continuously produced by the mitochondria in the brain, and its detoxification in the brain is carried out by GSH-dependent mechanisms; therefore, GR activity impairment causes GSH deficiency, and this contributes to the inability of $\mathrm{H}_{2} \mathrm{O}_{2}$ neutralization by GPx, which requires the presence of GSH. ${ }^{18}$ A previous study by Pearce et al. also showed GSH depletion in the substantia nigra of the midbrain of patients with PD. The depletion of GSH might indicate clinical susceptibility to the development of PD. The authors of the research indicate that GSH can be used as a biomarker for the diagnosis of these neurodegenerative diseases. Therefore, the activity of GSH-dependent enzymes may indirectly indicate the progression of the disease. ${ }^{19}$ The study by Zhou et al. suggests a possible correlation between severe dopamine oxidation and reduced protective potential of GSH. Additionally, the reduced GSH level significantly impairs the protective capacity of the brain from the toxic impacts of the oxidized dopamine molecules and ROS. ${ }^{20}$ The other enzyme along with the increased activity, which has been observed in the striatal of the subjects with PD, also plays an important role in protecting the tissues from free radicals. GST catalyzes the conjugation of glutathione with nucleophiles and electrophiles, resulting in the formation of glutathione conjugates. ${ }^{21}$

In addition to the degeneration of dopaminergic neurons in the striatum, extensive neurodegeneration and atrophy is observed in other types of nerve cells in the brain, including areas such as hippocampus, thalamus, cortex and cerebellum. This damage may cause the appearance of symptoms other than characteristic motor symptoms, which include, inter alia, cognitive impairments, affective changes, depression, psychosis, memory deficits and other non-motor symptoms. ${ }^{22}$ The chronic exposure to ROS can cause atrophy and abnormal functioning in many key areas of the brain structures, including the hippocampus and frontal cortex. ${ }^{23}$ It has been proved that atrophy of the hippocampus may be a biomarker of the early stages of cognitive disorders and memory disorders in patients with PD. ${ }^{24}$ Furthermore, cell damage in various regions of the brain reduces cognitive ability, causes deterioration of memory function, an increase of anxiety and depression levels in older rats with reduced dopamine and serotonin levels, in comparison with the group of young subjects. ${ }^{25}$ It seems that ROS may be involved in the processes damaging the hippocampus and cerebral cortex, because their long lasting high levels lead to the failure of antioxidant systems. Our studies also confirm this theory. They have also shown a significant reduction in the activity of GR, SOD, $\mathrm{Cu} / \mathrm{ZnSOD}$ and higher GPx activity and an increase of MDA production in the hippocampus of rats with $\mathrm{PD}$, compared to the control group, and a significantly lower activity of GR, SOD, MnSOD, CuSOD, and GST in the cerebral cortex of rats with PD group, as compared to healthy rats. A study conducted by Che et al. has shown that chronic stress resulting in ROS overproduction might damage the cerebral cortex and the hippocampus, which manifests in the reduced activity of antioxidant enzymes in the brains of rats exposed to chronic stress compared to the control group. Moreover, this study showed that reducing the antioxidant ability and induction of the lipid peroxidation in the cerebral cortex and hippocampus correlates positively with the severity of memory impairment, a decrease in learning abilities and the severity of depression. ${ }^{26}$ Looking at this study, it appears likely that the overproduction of free radicals and the progressive nature of PD supports the possibly negative impact of ROS in many areas of the brain, which reflects the appearance of clinical symptoms independent from the deficiency of dopamine and dopaminergic neurons. It is suggested that the overproduction of ROS is associated with a decrease in the antioxidant defense system during aging or as a result of an ongoing disease, which leads to the failure of cell homeostasis. Reduced expression or antioxidant deficiency may lead to excessive ROS production, and there is no possibility of removing them. ${ }^{27,28}$ Thalamus plays an important role in the proper communication between each brain structure. It is also responsible for the initial evaluation of sensory stimuli and then communicating this information from the first-order kernel to the cortex, while the higher-order kernel transmits the information from one area of the cortex to another. Thalamus plays a key role in the integration of sensory and motor information and attention processes, using cortico-thalamic loops. Thalamus also 
has connections to the hypothalamus and hippocampus. ${ }^{29}$ The cerebellum receives information from multiple brain systems; it is also responsible for maintaining balance of the body, coordination and dexterity and maintaining proper muscle tone, among other things. ${ }^{30}$ Our study shows that a significantly lower activity of GR, higher CAT activity and an increase in the concentration of MDA is observed in the thalamus of rats with PD, and a significantly higher activity of GR is detected in the cerebellum of rats with $\mathrm{PD}$, compared to the corresponding control group. Our study indicates that in the case of a reduction in GR activity in the striatum, cerebral cortex, hippocampus and thalamus, which might be one of the possible markers of $\mathrm{PD}$, a compensatory increase in the activity of other antioxidant enzymes is observed in brain structures including the striatum, hippocampus, thalamus, and cerebellum, which is aimed at protecting brain cells from damage caused by ROS.

Our research shows that oxidative stress in PD involves many brain structures and various antioxidant enzymes and oxidative status parameters become dysfunctional, depending on the area of the brain. The differences in the scope of changes in the antioxidant enzymes activity in various brain structures indicate that the mechanisms of oxidative damage are regional and specific. It seems that every cell or tissue has its own ROS defense system and in various areas under oxidative stress, different antioxidant enzymes, specific to the area of may deplete. It appears that the damage of various structures of the brain reflects the complex nature of the clinical symptoms of PD. Thus, the study on PD should not be limited to the analysis of changes in the substantia nigra and the striatum, but should also take into account other brain structures, the failure of which manifests itself in the form of clinical symptoms other than those of locomotion disorders. Future clinical and experimental studies should be directed to investigate molecular mechanisms of the neuronal damage by ROS. Understanding them may help in developing new approaches to neuroprotection. Further research, aimed at extending the knowledge about the specific mechanisms responsible for the modulation of ROS production in specific areas of the brain, is also required. In the available literature, only a few studies focus on the role of oxidative stress in damaging the brain structures other than the striatum in PD; therefore, there is a need for further studies, which will aim at expanding the concept presented by us.

\section{References}

1. Chinta SJ, Andersen JK. Redox imbalance in Parkinson's disease. Biochim Biophys Acta. 2008;1780:1362-1367.

2. Yuan H, Zheng JC, Liu P, Zhang SF, Xu JY, Bai LM. Pathogenesis of Parkinson's disease: Oxidative stress, environmental impact factors and inflammatory processes. Neurosci Bull. 2007;23:125-130.

3. Dias V, Junn E, Mouradian MM. The role of oxidative stress in Parkinson's disease. J Parkinsons Dis. 2013;3:461-491.

4. Zhou C, Huang Y, Przedborski S. Oxidative stress in Parkinson's disease: A mechanism of pathogenic and therapeutic significance. Ann N Y Acad Sci. 2008;1147:93-104.
5. Kostrzewa RM, Kostrzewa JP, Brus R, Kostrzewa RA, Nowak P. Proposed animal model of severe Parkinson's disease: Neonatal 6-hydroxydopamine lesion of dopaminergic innervation of striatum. J Neural Transm Suppl. 2006;70:277-279.

6. Richterich R. Chemia kliniczna. Warszawa: PZWL;1971.

7. Paglia DE, Valentine WN. Studies on the quantitative and qualitative characterization of erythrocyte glutathione peroxidase. J Lab Clin Med. 1967;70:158-169.

8. Habig, WH, Jakoby WB. Assays for differentiation of glutathione S-transferases. Methods Enzymol. 1981;77:398-405.

9. Oyanagui Y. Reevaluation of assay methods and establishment of kit for superoxide dismutase activity. Anal Biochem. 1984;142: 290-296.

10. Aebi H. Catalase in vitro. Methods Enzymol. 1984;105:121-126.

11. Ohkawa H, Ohishi N, Yagi K. Assay for lipid peroxides in animal tissues by thiobarbituric acid reaction. Anal Biochem. 1979;95:351-358.

12. Niranjan R. The role of inflammatory and oxidative stress mechanisms in the pathogenesis of Parkinson's disease: Focus on astrocytes. Mol Neurobiol. 2014;49:28-38.

13. Ross BM, Moszczynska A, Erlich J, Kish SJ. Low activity of key phospholipid catabolic and anabolic enzymes in human substantia nigra: Possible implications for Parkinson's disease. Neuroscience. 1998;83:791-798.

14. Kaur H, Chauhan S, Sandhir R. Protective effect of lycopene on oxidative stress and cognitive decline in rotenone induced model of Parkinson's disease. Neurochem Res. 2011;36:1435-1443.

15. Rodriguez-Rocha H, Garcia-Garcia A, Pickett C, et al. Compartmentalized oxidative stress in dopaminergic cell death induced by pesticides and complex I inhibitors: Distinct roles of superoxide anion and superoxide dismutases. Free Radic Biol Med. 2013;61:370-383.

16. Iglesias-González J, Sánchez-Iglesias S, Méndez-Álvarez E, et al. Differential toxicity of 6-hydroxydopamine in $\mathrm{SH}-\mathrm{SY} 5 \mathrm{Y}$ human neuroblastoma cells and rat brain mitochondria: Protective role of catalase and superoxide dismutase. Neurochem Res. 2012;37:2150-2160.

17. Choi J, Rees HD, Weintraub ST, Levey Al, Chin LS, Li L. Oxidative modifications and aggregation of $\mathrm{Cu}, \mathrm{Zn}$-superoxide dismutase associated with Alzheimer and Parkinson diseases. J Biol Chem. 2005;280:1648-1655.

18. Gu F, Chauhan V, Chauhan A. Glutathione redox imbalance in brain disorders. Curr Opin Clin Nutr Metab Care. 2015;18:89-95.

19. Pearce RK, Owen A, Daniel S, Jenner P, Marsden CD. Alterations in the distribution of glutathione in the substantia nigra in Parkinson's disease. J Neural Transm. 1997;104:661-677.

20. Zhou ZD, Lim TM. Roles of glutathione (GSH) in dopamine (DA) oxidation studied by improved tandem HPLC plus ESI-MS. Neurochem Res. 2009;34:316-326.

21. Smeyne M, Smeyne RJ. Glutathione metabolism and Parkinson's disease. Free Radic Biol Med. 2013;62:13-25.

22. Göttlich M, Münte TF, Heldmann M, Kasten M, Hagenah J, Krämer UM. Altered resting state brain networks in Parkinson's disease. PLoS One. 2013;8:e77336.

23. Wang $\mathrm{Y}$, Kan $\mathrm{H}$, Yin $\mathrm{Y}$, et al. Protective effects of ginsenoside Rg1 on chronic restraint stress induced learning and memory impairments in male mice. Pharmacol Biochem Behav. 2014;120:73-81.

24. Camicioli R, Moore MM, Kinney A, Corbridge E, Glassberg K, Kaye JA. Parkinson's disease is associated with hippocampal atrophy. Mov Disord. 2003;18:784-790.

25. Saleem S, Tabassum S, Ahmed S, Perveen T, Haider S. Senescence related alteration in hippocampal biogenic amines produces neuropsychological deficits in rats. Pak J Pharm Sci. 2014;27:837-845.

26. Che Y, Zhou Z, Shu Y, et al. Chronic unpredictable stress impairs endogenous antioxidant defense in rat brain. Neurosci Lett. 2015;584:208-213.

27. Chhunchha B, Fatma N, Kubo E, Rai P, Singh SP, Singh DP. Curcumin abates hypoxia-induced oxidative stress based-ER stressmediated cell death in mouse hippocampal cells (HT22) by controlling Prdx6 and NF-KB regulation. Am J Physiol Cell Physiol. 2013;304:C636-C655.

28. van Mierlo TJ, Chung C, Foncke EM, Berendse HW, van den Heuvel OA. Depressive symptoms in Parkinson's disease are related 
to decreased hippocampus and amygdala volume. Mov Disord. 2015;30:245-252.

29. Varela C, Sherman SM. Differences in response to serotonergic activation between first and higher order thalamic nuclei. Cereb Cortex. 2009;19:1776-1786.

30. Ebner TJ, Pasalar S. Cerebellum predicts the future motor state. Cerebellum. 2008;7:583-588. 